\title{
Adoptive Immunotherapy in Chimeras with Donor Lymphocytes
}

\author{
Hans-Jochem Kolb Christoph Schmid Xiao Chen Anja Woiciechowski \\ Marie Roskrow Martin Weber Wolfgang Guenther Georg Ledderose \\ Michael Schleuning
}

Clinical Cooperative Group Hematopoietic Cell Transplantation, Department of Medicine III,

Klinikum University of Munich-Grosshadern, and GSF-National Research Center for Environment and Health,

Munich, Germany

\section{Key Words}

Stem cell transplantation - Chimerism •

Transplantation tolerance - Adoptive immunotherapy · Donor lymphocyte transfusion

\begin{abstract}
Allogeneic stem cell transplantation has a well-defined indication in the treatment of hematological malignancies. The beneficial immune effect of allogeneic marrow transplantation has long been known, but only recently have methods been developed to separate the graft-versus-leukemia (GVL) effect from graft-versus-host disease (GVHD). Animal experiments have shown that lymphocytes from the marrow donor can be transfused without causing severe GVHD if stable chimerism and tolerance is established. First clinical studies have been preformed in patients with recurrent chronic myelogenous leukemia. In these patients complete molecular remissions were induced that persist without further maintenance treatment. These results have been confirmed in larger multicenter studies in Europe and the USA. The best results were obtained in chronic myelogenous leukemia $(\mathrm{CML})$; repeated successes have been reported in relaps-
\end{abstract}

ing acute myeloid leukemia (AML), myelodysplastic syndromes and multiple myeloma (MMY), and rare responses were reported for acute lymphoid leukemia. Contrary to animal experiments GVHD has been observed in human patients although to a lesser extent than expected in transplants not given immunosuppression. Secondly myelosuppression has been observed in patients treated with relapsing $\mathrm{CML}$. In CML the incidence of GVHD could be reduced by depleting CD8+ $T$ cells from the donor lymphocyte concentrate. Alternatively only small numbers of T lymphocytes can be transfused and in the case of failing responses, the numbers of donor lymphocytes may be increased. Results in recurrent $A M L$ have been improved by the use of lowdose cytosine arabinoside, granulocyte-macrophage colony-stimulating factor and granulocyte colony-stimulating factor mobilized blood cells as compared to lymphocytes only. In MMY the response rate is higher than in $A M L$, but the remissions are of limited duration in most patients. Several protocols have been designed to include preemptive donor lymphocyte transfusion in patients with a high relapse risk after transplantation. Problems remain to avoid chronic GVHD and to circumvent the immune escape mechanisms of leukemia.

Prof. Dr. Hans-Jochem Kolb, Hematopoietic Cell Transplantation

José Carreras Transplantation Unit, Klinikum University of Munich-Grosshadern

Marchioninistrasse 15, DE-81377 Munich (Germany)

Tel +49 897095 4240/4241, Fax +49897095 4242

E-Mail Kolb@med3.med.uni-muenchen.de 
The success of donor lymphocytes in the treatment of recurrent leukemia has changed the perspectives of hematopoietic stem cell transplantation [1]. The antileukemic effects of myeloablative conditioning have been substituted by adoptive immunotherapy using cells of the marrow donor (fig. 1). Formerly the treatment of leukemia and other neoplastic diseases of the hematopoietic system focused on the maximal tolerated dose of radiation and chemotherapy to destroy the leukemia as much as possible and to rescue the patient from hematopoietic failure by transplanting bone marrow. Today the limitations and risks of high-dose chemotherapy and radiotherapy are well known and the conditioning treatment is designed to allow the establishment of chimerism and the development of transplantation tolerance as a platform for immunotherapy. The conditioning does not need to be myeloablative. There is a therapeutic dilemma in bone marrow transplantation for malignant diseases. Acute graft-versus-host disease (GVHD) and its sequelae are the major complications of allogeneic stem cell transplantation. The most effective method to prevent GVHD is the depletion of T lymphocytes from the transplant [2, 3]. However, the depletion of $T$ cells from the graft ablated most of the antileukemic effect of allogeneic transplantation [4]. Adding back small amounts of T cells to the depleted graft was not successful in reducing the risk of relapse without inducing GVHD. However, transfusion of donor lymphocytes into stable canine chimeras did not produce GVHD [5]. Therefore in the 1980s we studied donor lymphocyte transfusions (DLTs) in canine chimeras with the aim of influencing chimerism and transfer immunity from the donor to the host [6].

The animal experiments encouraged us to use donor lymphocytes for the treatment of relapse of chronic myelogenous leukemia (CML) in 3 patients [7]. The results were confirmed by several single centers [8-14], and the spectrum of graft-versus-leukemia (GVL) activity was assessed in multicenter analyses $[15,16]$. Native donor lymphocytes and sensitized T cells, T-cell lines and clones were successful in the treatment of viral infections [1719]. Similar strategies have been explored using minor histocompatibility antigens with restricted tissue expression in the treatment of leukemia [20-22]. Here we review the current status of adoptive immunotherapy with donor cells and we try to give a perspective to the future of immunotherapy.

\section{Non-myeloablative conditioning stem cell transplantation $\downarrow$ Chimerism \& Tolerance $\downarrow$}

Adoptive immunotherapy with specific T-cells \pm dendritic cells

Fig. 1. Strategy of adoptive immunotherapy in chimeras. Adoptive immunotherapy with $\mathrm{T}$ cells with or without dendritic cells allows non-myeloablative conditioning. As soon as chimerism is stable and immunosuppression can be discontinued, a state of immunological tolerance is established. At this time donor cells can be transfused without severe GVHD.

\section{Principles Derived from Animal Studies}

There have been many studies on murine leukemia which differs in several aspects from human leukemia. Bacteria-free mice with spontaneous AKR leukemia have been treated with some success using marrow and lowdose lymphocytes from major histocompatibility complex (MHC) mismatched donors [23].

The concept that leukemia expresses minor histocompatibility antigens on the hematopoietic cells of the host was the starting point for the production of mixed DLAidentical chimeras in dogs. Conversion of mixed chimerism into complete chimerism served as a model for a GVL reaction. Mixed chimeras were produced by transplantation of low numbers of marrow cells depleted of T cells by the treatment with absorbed antithymocyte globulin (ATG) to prevent GVHD. These animals were stable mixed chimeras. Transfusion of donor lymphocytes on days 1 and 2, or days 21 and 22 after marrow transplantation induced fatal GVHD. However, transfusion on days 61 and 62 did not produce GVHD and the animals survived. These animals were mixed lymphoid and myeloid chimeras prior to transfusion and they became complete chimeras thereafter [6]. The donors were immunized against tetanus toxoid and the recipients developed antibody titers after DLT that persisted for more than 3 years after booster injections. Transfused and nontransfused animals were immunized against diphtheria toxoid as a new antigen. Transfused dogs developed significantly higher antibody titers than nontransfused dogs.

Acta Haematol 2003;110:110-120 
Fig. 2. The course of a 39-year-old patient suffering from myelosuppression following DLT. After DLT WBC increased and the patient developed fever until the blood counts dropped and the patient became severely pancytopenic. Transfusion of marrow from his donor without further conditioning resulted in complete restoration of hematopoiesis and complete chimerism. A molecular remission was found after marrow transfusion that persists until presence.

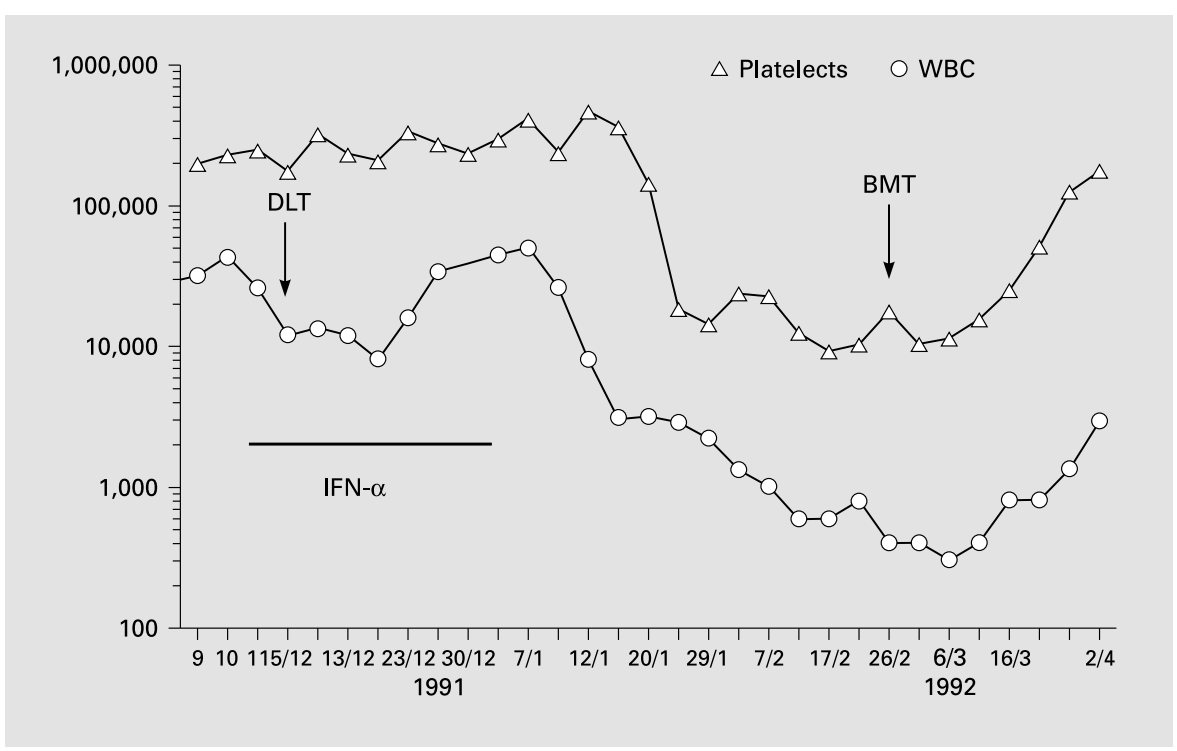

In mice a delay of 3 weeks for the transfusion of donor lymphocytes was enough to prevent GVHD [24].

The importance of the delay of DLT is obvious, but the cause of GVHD is not clear. One possibility is the "cytokine storm' set free by the conditioning treatment with radiation and chemotherapy [25] that may have settled after 3 weeks and 2 months, respectively. Another possibility is the establishment of peripheral tolerance maintained by donor $T$ cells in collaboration with host dendritic cells. The latter mechanism is supported by the finding that depletion of donor lymphocytes in the chimera prior to DLT predisposes the recipient to vigorous GVHD (Menzel H, 1996, unpublished) [26]. In man the necessary delay is not known. It may vary with age and previous chemo- and radiotherapy.

\section{Results of DLTs in CML}

Three patients with recurrent CML after allogeneic marrow transplantation were treated with DLT in 1988 and 1989 [27], they are still in hematologic and molecular remission of CML. Acute GVHD developed in 2 patients requiring immunosuppressive treatment, and chronic GVHD in 1. Immunosuppressive treatment could be discontinued in both. Severe myelosuppression was observed in a 4th patient treated 1991. Pancytopenia occurred 2 months after DLT and it did not respond to treatment with granulocyte colony-stimulating factor, but to the transfusion of donor marrow (fig. 2).
The analysis of the results of centers of the European Cooperative Group of Blood and Marrow Transplantation (EBMT) showed best results in cytogenetic and hematologic relapses of CML, intermediate results in transformed phase CML, acute myeloid leukemia (AML) and myelodysplastic syndromes (MDS), and poor results in acute lymphoblastic leukemia (ALL) [15]. Single patients with chronic myeloproliferative diseases as polycythemia vera and myeloid fibrosis [28] also responded to DLT. Both the absence of chimerism [29] and the presence of GVHD at the time of DLT were adverse factors for a response. In CML the GVL effect correlated with the severity of GVHD, but responses were also seen in patients without GVHD. However GVL was limited to patients with an allogeneic donor, it failed in patients with a monozygotic twin donor. The time until molecular remission was between 4 and 6 months after a single transfusion in most patients; in some patients molecular remissions were reached after more than a year (fig. 3). Antigen presentation could be improved by treatment with cytokines. In particular the combination of interferon- $\alpha($ IFN- $\alpha$ ) and granulocyte-macrophage colony-stimulating factor (GM-CSF) improved the expression of class-I and II human lymphocyte antigens (HLAs), CD40 and CD80 [30]. Preliminary results confirm the beneficial effect of GM-CSF and IFN- $\alpha$ in patients with recurrent CML refractory to donor lymphocytes.

Complications of the treatment were GVHD and myelosuppression. Myelosuppression was more frequent in hematological relapse than in cytogenetic relapse. The 
use of mobilized blood cells containing stem cells instead of lymphocytes did not prevent myelosuppression [31]. Prevention of GVHD could be achieved by two methods without ablating the GVL effect: depletion of CD8+ T cells from the transfusion [32, 33], and using escalating doses of DLT [34] starting at $2 \times 10^{6}$ lymphocytes $/ \mathrm{kg}$. The escalating dose schedule has significantly lowered the risk of GVHD [35]. Patients should be surveyed by regular quantitative reverse transcriptase polymerase chain reaction for bcr/abl, and in case of persisting or recurrent positivity the proposed schedule is started at a dose of $2 \times$ $10^{6}$ lymphocytes/kg from unrelated donors and $1 \times 10^{7}$ lymphocytes/kg from an HLA-identical sibling donor. Doses are escalated if there is no GVHD within 30 days or no response within 60 days.

\section{Results of DLTs in AML and MDS}

The EBMT results indicated inferior responses in patients with recurrent AML after DLT. In patients without chemotherapy-induced remission the response rate was $25 \%$ with very few patients surviving more than 4 years. In a second analysis of 120 patients with AML and MDS reported to the EBMT, complete remissions could be induced in 45 (41.6\%) of 108 evaluable patients including patients treated with chemotherapy and DLT [36]. The median duration of remission was 304 days, in 18 patients remissions lasted more than a year, and in single patients more than 5 years. Overall survival was greater in responding patients. Three risk factors could be identified as being associated with a poor response to DLT: a short remission after allogeneic transplantation of less than the median of 194 days $(\mathrm{p}=0.02)$; withholding chemotherapy prior to DLT ( $p=0.001)$, and the absence of acute GVHD of grade II or higher after DLT $(\mathrm{p}<0.0001)$. Of patients without GVHD only $18 \%$ responded as compared to $66 \%$ of patients with GVHD > grade I. Patients with late relapse after transplantation responded more frequently $(48 \%)$ than those with early relapse $(28 \%)$. After DLT the complete remission rate was independent of gender and age of the patient and donor, their relationship, the number of cells transfused and whether or not T-cell depletion was used for prophylaxis of GVHD after transplantation. Survival of patients without complete remission was poor, but once a complete remission was achieved survival was not different whether or not the remission was induced by chemotherapy. This finding supports the hypothesis that DLT maintains the remission and favors the use of chemotherapy for remission induction.

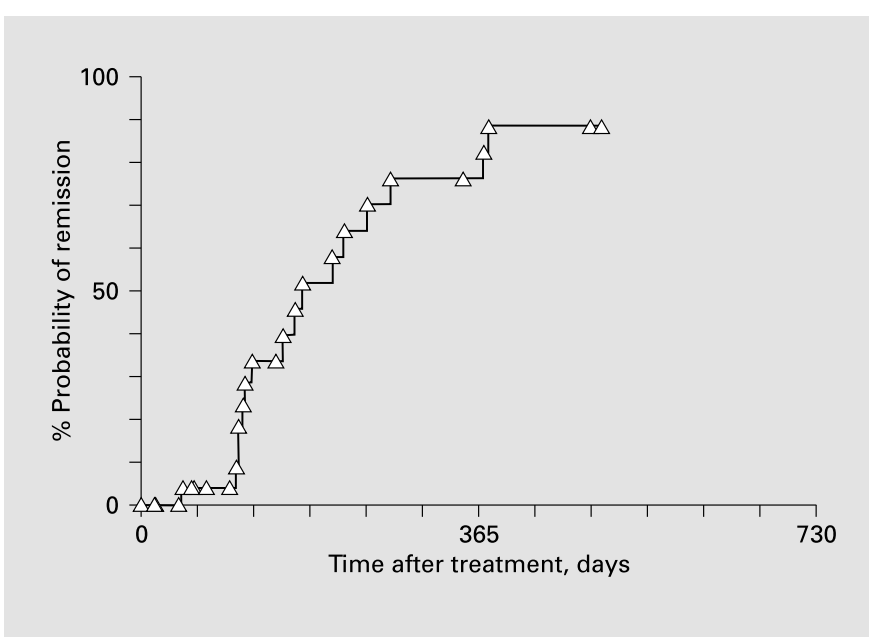

Fig. 3. Time to molecular remission after DLT. Molecular remissions were achieved after 4 months, the median time was 6 months and late remissions occurred after more than 1 year. Data are from the Transplant Center Munich Grosshadern, evaluated in March 2001.

Only limited data were available on the FAB subtype and cytogenetic analyses in these patients. With these limitations neither the FAB subtype nor the karyotype influenced the response.

Poor antigen presentation and the rapid progression of the disease were considered as the major obstacles for adoptive immunotherapy in recurrent AML. Improvement of antigen presentation and production of cytotoxic $\mathrm{T}$ cells against autologous blasts was studied in vitro (fig. 4). The combination of GM-CSF, IL-4, TNF- $\alpha$ and FLT3-L was particularly effective in inducing dendritic cells from AML blasts [37]. The culture was effective in $77 \%$ of patients and included patients with unfavorable karyotypes. Specific cytotoxic T cells against autologous blasts could be produced in more than $60 \%$ of these patients.

In a recent study we have used low-dose cytosine arabinoside as mild chemotherapy for halting progression of the disease and GM-CSF for improving antigen presentation. Mobilized blood (MDBC) was transfused as a preparation of stem cell-enriched donor lymphocytes and GMCSF was applied for 14-28 days after transfusion. This way antigen presentation was optimized by induction of dendritic cells from AML blasts and substitution of dendritic cells derived from CD34+ cells of the graft. The response rate was improved from 25 to $67 \%$ and the actuarial probability of survival is $25 \%$ at 4 years [38]. In 


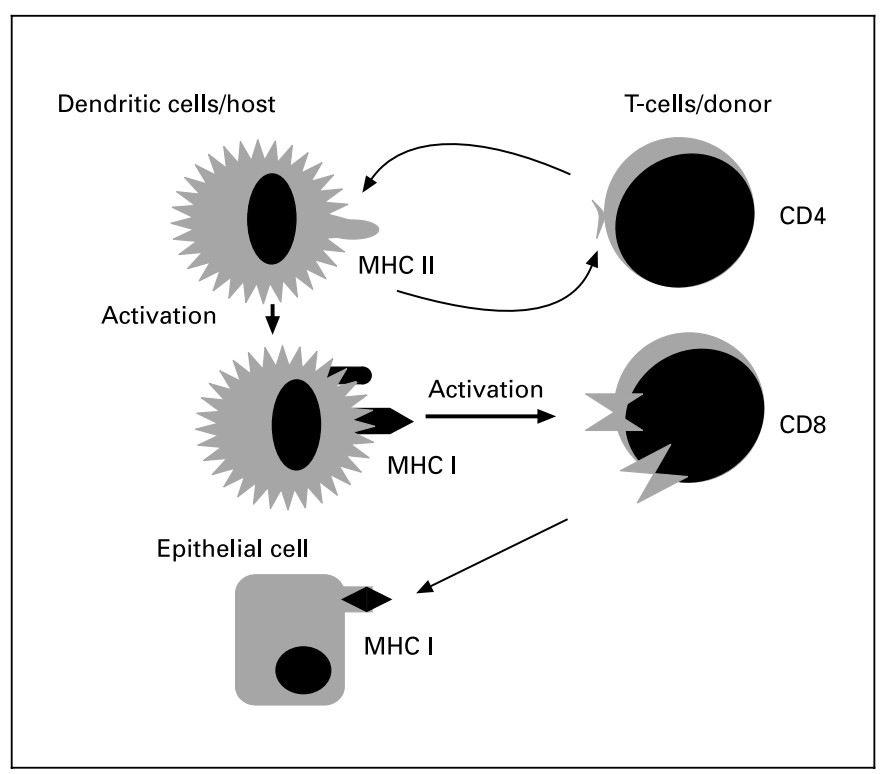

Fig. 4. Pathophysiology of GVHD. There is mutual activation of donor CD4+ T cells and host dendritic cells which may be accelerated by pre-activation of dendritic cells by radiation, chemotherapy, endotoxin from intestinal flora, viral infections and by pre-immunization on the side of the $T$ cells against minor histocompatibility antigens, viral antigens and others. Activated dendritic cells activate CD8+ T cells and present HLA class-I-restricted peptides to CD8 T cells which become activated and react against normal cells of the host.

some responding patients the treatment was repeated after 4-6 months, and the patients have remained in remission.

In patients with progressive disease after MDBC, lowdose cytosine arabinoside and the transfusion of donor $\mathrm{T}$ cells has been used with success, but GVHD was mostly severe.

GVHD and extramedullary relapses remain therapeutic problems. In most patients with extramedullary relapse and some patients with systemic relapse, low-dose cytosine arabinoside is not effective in halting disease progression. In these more intensive chemotherapy including anthracyclins is necessary; solitary infiltrates may be radiated prior to transfusion of donor cells [39]. Following more intensive chemotherapy severe GVHD may develop after transfusion of mobilized blood cells and treatment with GM-CSF. In these cases GM-CSF has to be stopped and immunosuppressive treatment with steroids, cyclosporin A and azathioprine or others has to be started. GM-CSF should also be discontinued if blasts are mobilized from the marrow into the blood. Unfortunately leu- kemia may recur during immunosuppressive treatment and few therapeutic options remain.

\section{Results of DLTs in Myeloma}

The best responses next to CML were seen in recurrent multiple myeloma [40-42]. The most sensitive marker for response is the monoclonal paraprotein, next are infiltrates of plasma cells in the marrow and the disappearance of lumps, and the least sensitive are osteolytic lesions. The time to response may be 4-6 months or longer, and unlike in CML hematological remissions are less likely to be complete [43]. In most instances remissions are not as durable as in CML, but durable partial remissions have been observed in single patients (Kolb, unpublished). GVHD is observed in most responding patients, it may even recur after chemotherapy for myeloma [44]. Prevention of GVHD by depletion of CD8+ T cells from DLT was used with some success [33], repeated low doses of unseparated DLT were also effective [45].

Preemptive treatment with DLT may improve the outcome in combination with T-cell depletion, but the optimal strategy has not been found [46]. Immunization of a donor against the idiotype of the myeloma and the transfer of a cellular proliferative response has been reported [47], but the reactive donor $\mathrm{T}$ cells were found in the patient with persisting paraprotein.

\section{Results of DLTs in Other Diseases}

The response of recurrent ALL to DLT was poor in most cases [5, 48], but there are exceptions with long-lasting remissions [49, 50]. The first case of Slavin et al. [13] was a child with ALL who received donor cells 4 weeks after transplantation for residual leukemia. Remissions have been described in patients with Hodgkin's disease, non-Hodgkin's lymphoma [51] and chronic lymphocytic leukemia, but the overall response is controversial.

Neoplastic diseases other than hematological have been treated with allogeneic transplantation and DLT with some success. Metastatic renal cell cancer has shown sustained responses [52], some response was also observed in breast [53] and ovarian cancer (Kolb unpublished).

Non-malignant diseases have benefited from DLT in cases of poor graft function after non-myeloablative conditioning [54]. Allogeneic transplantation and DLT have been advocated for the treatment of autoimmune diseases 
[55], since patients with autoimmune disease who had been transplanted for leukemia were cured of the autoimmune disease in most instances. However, chronic GVHD may complicate allogeneic stem cell transplantation after non-myeloablative conditioning with symptoms similar to those of autoimmune diseases.

DLTs have been used for the treatment of viral infections after transplantation, in particular Epstein-Barr virus-induced lymphoproliferative disease [18]. In these cases minute numbers of $T$ cells were sufficient and the reactions were associated with an acute inflammatory response. Pre-immunized T-cell lines were better tolerated and effective [19]. Adoptive immunotherapy of viral infections has shown promising results which may lead to better understanding of the GVL response.

\section{Mechanism of the GVL (Tumor) Effect}

The absence of a measurable GVL effect in patients with syngeneic twin donors indicates the importance of an alloimmune response [15]. Minor histocompatibility antigens are expressed on leukemia cells and can serve as targets for a GVL effect without GVHD, if their expression is restricted to hematopoietic tissue [22, 56]. HA-1 and HA-2 are such peptides with restricted expression to the hematopoietic system, but Y-associated minor histocompatibility antigens are also candidates [57, 58]. Tissuerestricted expression of minor histocompatibility antigens may be operationally limited to the hematopoietic system by presentation of class-II HLAs [59].

The effector cells of the GVL reaction are not well defined. CD4+ T cells might be candidates, since CD8+ T cells could be depleted without losing the GVL effect [32]. However CD4+ T cells can recruit CD8+ T cells and other cells in vivo [60].

There is good evidence that ex vivo T cells immunized against minor histocompatibility antigens effectively lyse leukemia cells in vitro $[21,61]$ and in immunodeficient mice in vivo [62]. However, ex vivo immunized $\mathrm{T}$ cells have not yet been used widely in human patients. The most convincing example of leukemia treatment with immunized cells is the trial of Falkenburg et al. [63] who selected cytotoxic $\mathrm{T}$ cells on the basis of their reactivity to CML cells and infused them repeatedly into a patient with accelerated phase CML. Slavin et al. [64] immunized donor cells with cell lysates of the parents and found a complete response in a patient with accelerated phase CML who had not responded to DLT.

Adoptive Immunotherapy in Chimeras with Donor Lymphocytes
Antigens other than minor histocompatibility antigens that may be candidates for a GVL effect comprise fusion peptides, peptides from proteins encoded by mutated genes and proteins of overexpressed genes. Products of disease-specific rearranged genes as BCR/ABL in CML, PML/RAR $\alpha$ in AML FAB M3 and AML1/ETO and others contain highly specific fusion peptides. Proteins of genes with point mutations as in RAS genes and peptides of overexpressed normal genes such as $\mathrm{p} 53$ and proteinase 3 [65] have been studied. The antibody idiotype of a lymphoma and myeloma could also be seen as an overexpressed normal protein that marks the tumor. T-cell reactivity has been described for all of these, but only BCR/ ABL-specific $T$ cells recognize malignant cells in patients, and $T$ cells with that specificity are occasionally found in patients [66]. To date none of these antigens has been used successfully for adoptive immunotherapy in chimeric patients [67].

Our hypothesis that because myeloid leukemia produces dendritic cells of leukemia origin it responds better to DLT than lymphoid leukemia has been supported by the finding that dendritic cells in CML carry the bcr/abl translocation [30, 68, 69], and AML cells differentiated the karyotypic marker to dendritic cells $[37,70]$ in fluorescent in situ hybridization (FISH).

The production of dendritic cells from leukemia precursors has been studied in vitro because most cases of AML, as lymphomas and lymphoblastic leukemia, do not express co-stimulatory molecules such as CD80 and CD86. Untreated CML is poorly stimulatory in mixed lymphocyte reactions and fails to induce cytotoxic $\mathrm{T}$ cells in many instances [71]. Culture of AML blasts in the presence of GM-CSF, IL-4 with or without TNF- $\alpha$ and FLT3$\mathrm{L}$ induces the expression of co-stimulatory molecules [37] (fig. 5). Similarly culture of CML cells in the presence of IFN- $\alpha$ and GM-CSF stimulates expression of co-stimulatory molecules and the generation of cytotoxic T lymphocytes [72]. The combination of GM-CSF and IFN- $\alpha$ has already been used successfully in patients with relapse of CML not responding to DLT alone and DLT plus IFN- $\alpha$ (unpublished). Other cytokines such as IL-2 have been introduced on the basis of animal experiments [73]. IL-2 may support the T-cell reactivity after immunization. In myeloma and lymphoid neoplasms stimulation of donor $\mathrm{T}$ cells is poor and new ways to improve specific T-cell stimulation are being explored. One possibility is the transfer of genes coding for immunostimulatory molecules and proinflammatory cytokines [74]. Other ways are the transfusion of dendritic cells with the DLT or the use of MDBC together with the treatment with GM-CSF.

Acta Haematol 2003;110:110-120 


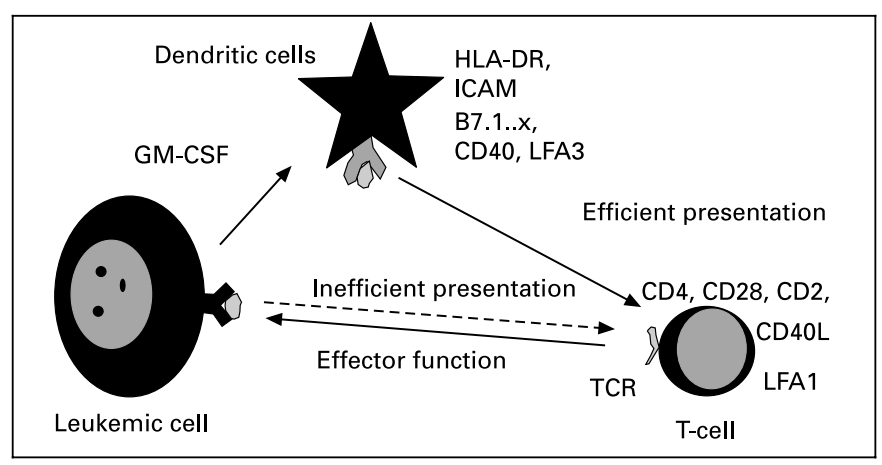

Fig. 5. AML cells may develop to antigen-presenting cells. AML blasts are deficient of co-stimulatory molecules and are thus inefficient in the presentation of antigen to donor $T$ cells. Treatment with GM-CSF drives blasts to express the stimulatory molecules necessary for efficient antigen presentation. These $\mathrm{T}$ cells then react against residual blasts.
Table 1. Possible mechanisms of immune escape

\section{Mechanisms on antigen presentation}

Low expression of co-stimulatory molecules: B7.1, B7.2, CD40, ICAM

Downregulation of HLA class I, class II antigens or relevant alleles Inefficient peptide production by proteasome/TAP mechanism

Secretion of inhibitory cytokines as IL-10, TGF- $\beta$

Low secretion of proinflammatory cytokines TNF- $\alpha$ and IFN- $\gamma$

Expression of FAS-L on tumor/leukemia cells inducing apoptosis of T cells

Expression of nonfunctional FAS on leukemia blasts

\section{Mechanisms on T cells}

Downregulation of $\zeta$-chain (lymphoma and CML) and \&-chain

(CML) of the $\mathrm{T}$ cell receptor

Downregulation of CD28 in AML

Others
Fig. 6. Mechanism of the graft-versus-leukemia reaction. After establishment of chimerism dendritic cells of the host are replaced by dendritic cells of the donor. Leukemic blasts are potentially the remaining hematopoietic cells of the host which may become stimulatory and a target for donor $\mathrm{T}$ cells, if they are driven towards dendritic cells. The reaction is specific because minor histocompatibility antigens with restricted expression are involved and donor dendritic cells maintain tolerance in other organs.

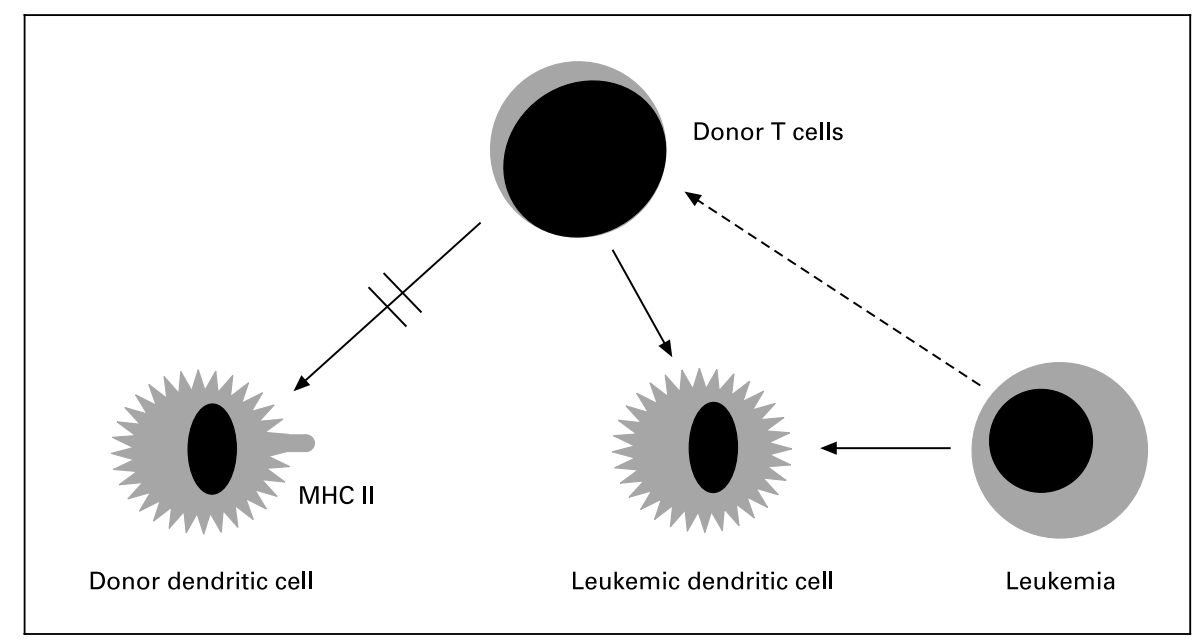

Immune reconstitution after DLT has been studied with typing for T-cell receptor V- $\beta$ families [75] and T-cell receptor excision circles [76]. DLT enhanced immune recovery and converted to full donor chimerism. In single patients with GVL reactions clonal T-cell restitution has been observed [75]. T cells of the donor produced similar clones when exposed to the leukemia in vivo as in vitro, but genetic analysis showed that they were different [77].

Intercurrent infections with viruses or other intracellular microorganisms may jeopardize the result of DLT. Most patients experiencing viral infections in the first weeks after DLT develop GVHD. A similar observation has been reported in patients given T-cell-depleted transplants and DLT. CMV seropositivity of the patient was the most significant risk factor for survival [78]. It is being discussed whether anti-infectious prophylaxes should be given to patients after DLT.

There are numerous mechanisms how neoplasms and leukemia may escape an immune reaction against themselves (table 1) [79]. Most importantly the expression of antigens on the cell surface may change. Even the loss of the Philadelphia chromosome has been reported [80]. In this context the use of minor histocompatibility antigens is most promising, because in the chimera most hematopoietic cells are substituted by the donor and only leukemia cells are still of host type (fig. 6).

The role of natural killer (NK) cells has always been debated in allogeneic stem cell transplantation. During 
post-transplant recovery NK cells are early and trials of substitution early after transplantation have not been successful. In murine models allogeneic NK cells were effective [81], but depletion of $\mathrm{CD} 3+\mathrm{T}$ cells abrogated the effect [82]. In HLA-mismatched transplantation complete T-cell chimerism is not required for GVL to occur, mixed chimeras can be cured of lymphoma [83]. In mixed chimeras DLT exert a strong effect against lymphoma without causing GVHD [84]. The role of NK cells has recently been investigated in HLA-mismatched transplantation and excellent results were reported in AML, if donor and patient differed in the killer inhibitor receptors [85]. NK cells are inhibited from killing if the target cells share certain HLA antigens. In HLA-mismatched transplantation NK cells of the donor can kill leukemia cells and at the same time suppress rejection of the transplant. In the case of the donor and patient belonging to a different alloreactive group, relapses of AML did not occur.

\section{Outlook for Adoptive Immunotherapy}

Hematopoietic cell transplantation has come a long way from bone marrow transplantation to adoptive immunotherapy in chimeras. However, the mechanisms of adoptive immunotherapy in chimeras are still far from being understood. The immunobiology of leukemia, other neoplasia and viral infections has to be studied further in human patients. The mechanism of immune tolerance, immune reactivity against normal cells, and transfer of immunity can be studied in animal experiments.

Immunization of donor $\mathrm{T}$ cells against minor histocompatibility antigens of the recipient is currently studied in the dog. Sensitized cells convert mixed to complete chimerism much faster than naive $\mathrm{T}$ cells. Tests have been developed to demonstrate cellular immunity to hematopoietic progenitor cells in vitro allowing the definition of minor antigens in the dog [86]. The incidence of severe GVHD after transfusion of sensitized donor lymphocytes into stable chimeras may be 30-50\% [5]. The percentage is expected to be higher in humans since patients and their donors are exposed to a multiplicity of histocompatibility and viral antigens during their life. Preventive measures against severe GVHD are necessary. Modification of donor lymphocytes with a suicide gene is the most promising way of prevention. T cells of the donor are infected with a replication-deficient retrovirus carrying the herpes simplex thymidine kinase gene (HSV-Tk) which can phosphorylate ganciclovir and the resulting nucleotide leads to the stop of DNA polymerization during cell division [87].
Current problems of the method are altered immune reactivity of transduced $T$ cells, immune reaction against the viral protein and rejection of the transduced cells and altered sensitivity of transduced cells to ganciclovir due to splice variants of the gene. Recently the development of leukemia has been reported in a mouse treated with cells carrying the marker gene (a truncated nerve growth factor receptor) without the suicide gene. We have studied the method in the dog and found a good immune reactivity of transduced canine $T$ cells in vitro. Transfusion of transduced $T$ cells into a canine chimera resulted in a complete chimerism and transfer of immunity to tetanus toxoid [88].

Adoptive immunotherapy in chimeras is a promising way to treat leukemia and possibly solid neoplasia. In particular the immune reactivity against leukemias and neoplasia otherwise refractory to chemotherapy gives new perspectives in hematology and oncology. Several leukemia study groups have included preemptive DLT as prophylaxis in high-risk leukemia according to the schema shown in figure 1 . The results are pending.

\section{Acknowledgments}

This work was supported by the Deutsche Forschungsgemeinschaft, Project Ko 81-1383-2, Wilhelm Sander Stiftung No. 93-01801-03, and Deutsche José Carreras Leukämie Stiftung e.V. 


\section{References}

1 Antin JH: Graft-versus-leukemia: No longer an epiphenomenon. Blood 1993;82:2273-2277.

2 Rodt H, Kolb HJ, Netzel B, Rieder I, Janka G, Belohradsky B, Haas RJ, Thierfelder S: GVHD suppression by incubation of bone marrow grafts with anti-T- cell globulin: Effect in the canine model and application to clinical bone marrow transplantation. Transplant Proc 1979;11:962-966.

3 Kolb HJ, Rieder I, Rodt H, Netzel B, Grosse Wilde H, Scholz S, Schaffer E, Kolb H, Thierfelder S: Antilymphocytic antibodies and marrow transplantation. Vl: Graft-versus-host tolerance in DLA-incompatible dogs after in vitro treatment of bone marrow with absorbed antithymocyte globulin. Transplantation 1979;27: 242-245.

4 Horowitz MM, Gale RP, Sondel PM, Goldman JM, Kersey J, Kolb HJ, Rimm AA, Ringden O, Rozman C, Speck B, et al: Graft-versus-leukemia reactions after bone marrow transplantation. Blood 1990;75:555-562.

5 Weiden PL, Storb R, Tsoi M-S, Graham TC, Lerner KG, Thomas ED: Infusion of donor lymphocytes into stable canine radiation chimeras. Implications for mechanism of transplantation tolerance. J Immunol 1976;116 1212-1219.

6 Kolb HJ, Günther W, Schumm M, Holler E, Wilmanns W, Thierfelder S: Adoptive immunotherapy in canine chimeras. Transplantation 1997;63:430-436.

7 Kolb HJ, Mittermueller J, Clemm C, Ledderose $\mathrm{G}$, Brehm G, Heim M, Wilmanns W Donor leukocyte transfusions for treatment of recurrent chronic myelogenous leukemia in marrow transplant patients. Blood 1990;76: 2462-2465.

8 Bar BMAM, Schattenberg A, Mensink EJBM, Van Kessel AG, Smetsers TFCM, Knops GHJN, Linders EHP, De Witte T: Donor leukocyte infusions for chronic myeloid leukemia relapsed after allogeneic bone marrow transplantation. J Clin Oncol 1993;11:513-519.

9 van Rhee F, Lin F, Cullis JO, Spencer A, Cross NCP, Chase A, Garicochea B, Bungey J, Barrett AJ, Goldman JM: Relapse of chronic myeloid leukemia after allogeneic bone marrow transplant: The case for giving donor leukocyte transfusions before the onset of hematological relapse. Blood 1994;83:3377-3383.

10 Hertenstein B, Wiesneth M, Novotny J, Bunjes D, Stefanic M, Heinze B, Hübner G, Heimpe $\mathrm{H}$, Arnold R: Interferon alpha and donor buffy coat transfusions for treatment of relapsed chronic myeloid leukemia after allogeneic marrow transplantation. Transplantation 56 1114-1118. 1993.

11 Helg C, Roux E, Beris P, Cabrol C, Wacker P, Darbellay R, Wyss M, Jeannet M, Chapuis B, Roosnek E: Adoptive immunotherapy for recurrent CML after BMT. Bone Marrow Transplant 1993;12:125-129.
12 Porter DL, Roth MS, McGarigle C, Ferrara JLM, Antin JH: Induction of graft-versus-host disease as immunotherapy for relapsed chronic myeloid leukemia. N Engl J Med 1994;330: 100-106.

13 Slavin S, Naparstek E, Nagler A, Ackerstein A, Samuel S, Kapelushnik J, Brautbar C, Or R: Allogeneic cell therapy with donor peripheral blood cells and recombinant human interleukin-2 to treat leukemia relapse after allogeneic bone marrow transplantation. Blood 1996;87: 2195-2204.

14 Bacigalupo A, Soracco M, Vassallo F, Abate M, van Lint MT, Gualandi F, Lamparelli T, Occhini D, Mordini N, Bregante S, Figari O, Benvenuto F, Sessarego M, Fugazza G, Carlier P, Valbonesi M: Donor lymphocyte infusions (DLI) in patients with chronic myeloid leukemia following allogeneic bone marrow transplantation. Bone Marrow Transplant 1997;19: 927-932.

15 Kolb HJ, Schattenberg A, Goldman JM, Hertenstein B, Jacobsen N, Arcese W, Ljungman $\mathrm{P}$, Ferrant A, Verdonck L, Niederwieser D, van Rhee F, Mittermüller J, De Witte T, Holler E, Ansari H: Graft-versus-leukemia effect of donor lymphocyte transfusions in marrow grafted patients. Blood 1995;86:2041-2050.

16 Collins RH, Shpilberg O, Drobyski WR, Porter DL, Giralt S, Champlin R, Goodman SA, Wolff SN, Hu W, Verfaillie C, List A, Dalton W, Ognoskie N, Chetrit A, Antin JH, Nemunaitis J: Donor leukocyte infusions in 140 patients with relapsed malignancy after allogeneic bone marrow transplantation. J Clin Oncol 1997; 15:433-444.

17 Riddell SR, Watanabe KS, Goodrich JM, Li CR, Agha ME, Greenberg PD: Restoration of viral immunity in immunodeficient humans by adoptive transfer of T-cell clones. Science 1992;257:238-241.

18 Papadopoulos EB, Ladanyi M, Emanuel D, Mackinnon S, Boulad F, Carabasi MH, CastroMalaspina H, Childs BH, Gillio AP, Small TN, Young JW, Kernan NA, OReilly RJ: Infusions of donor leukocytes to treat Epstein-Bar virusassociated lymphoproliferative disorders after allogeneic bone marrow transplantation. N Engl J Med 1994;330:1185-1191.

19 Heslop HE, Brenner MK, Rooney CM: Donor $\mathrm{T}$ cells to treat EBV-associated lymphoma. N Engl J Med 1994;331:679-680.

20 van der Harst D, Goulmy E, Falkenburg JHF, Kooji-Winkelaar YMC, van Luxemburg-Heijs SAP, Goselink HM, Brand A: Recognition of minor histocompatibility antigens on lymphocytic and myeloid leukemic cells by cytotoxic T-cell clones. Blood 1994;83:1060-1066.

21 Mutis T, Verdijk R, Schrama E, Esendam B, Brand A, Goulmy E: Feasability of immunotherapy of relapsed leukemia with ex vivo generated cytotoxic $\mathrm{T}$ lymphocytes specific for hematopoietic system-restricted minor histocompatibility antigens. Blood 1999;93:2336-2341.
22 Warren EH, Greenberg PD, Riddell SR: Cytotoxic T-lymphocyte-defined human minor histocompatibility antigens with a restricted tissue distribution. Blood 1998;91:2197-2207.

23 Truitt RL, Shih CC, LeFever AV: Manipulation of graft-versus-host disease for a graft-versus-leukemia effect after allogeneic bone marrow transplantation in AKR mice with spontaneous leukemia/lymphoma. Transplantation 1986;41:301-310

24 Johnson BD, Drobyski WR, Truitt RL: Delayed infusion of normal donor cells after MHC-matched bone marrow transplantation provides an antileukemia reaction withou graft-versus-host disease. Bone Marrow Transplant 1993;11:329-336.

25 Ferrara JLM, Deeg HJ: Graft-versus-host disease. N Engl J Med 1991;324:667-674.

26 Johnson BD, Becker EE, LaBelle JL, Truitt RL: Role of immunoregulatory donor T cells in suppression of graft-versus-host disease following donor leukocyte infusion therapy. J Immunol 1999;163:6479-6487.

27 Kolb HJ, Mittermueller J, Holler E, Clemm C, Ledderose G, Brehm G, Wilmanns W: Treatment of recurrent chronic myelogenous leukemia posttransplant with interferone alpha (INFa) and donor leukocyte transfusions. Blut 1990;61:122.

28 Cervantes F, Rovira M, Urbano-Ispizua A, Rozman M, Carreras E, Montserrat E: Complete remission of idiopathic myelofibrosis following donor lymphocyte infusion after failure of allogeneic transplanta-tion: Demonstration of a graft-versus-myelofibrosis effect. Bone Marrow Transplant 2000;26:697-699.

29 Schattenberg A, Schaap N, van de Wiel-van Kemenade E, Bar B, Preijers F, Van Der Maazen R, Roovers E, De Witte T: In relapsed patients after lymphocyte depleted bone marrow transplantation the percentage of donor $\mathrm{T}$ lymphocytes correlates well with the outcome of donor leukocyte infusion. Leuk Lymphoma 1999;32:317-325

30 Chen X, Regn S, Raffegerst S, Kolb HJ, Roskrow $\mathrm{M}$ : Interferon alpha in combination with GM-CSF induces the differentiation of leukaemic antigen-presenting cells that have the capacity to stimulate a specific anti-leukaemic cytotoxic T-cell response from patients with chronic myeloid leukaemia. $\mathrm{Br} \mathrm{J}$ Haematol 2000;111:596-607.

31 Flowers MED, Sullivan KM, Martin P, Buckner CD, Beach K, Higano T, Radich JP, Clift RA, Bensinger W, Deeg HJ, Chauncey TR, Rowley S, Storb R, Appelbaum FR: G-CSF stimulated donor peripheral blood infusions as immunotherapy in patients with hematologic malignancies relapsing after allogeneic transplantation (abstract). Blood 1995;86(supp 1):564.
Kolb/Schmid/Chen/Woiciechowski/ Roskrow/Weber/Guenther/Ledderose/ Schleuning 
32 Giralt S, Hester J, Huh Y, Hirsch-Ginsberg C, Rondon G, Seong D, Lee M, Gajewski J, Van Besien K, Khouri I, Mehra R, Przepiorka D, Körbling M, Talpaz M, Kantarjian H, Fischer $\mathrm{H}$, Deisseroth A, Champlin R: CD8-depleted donor lymphocyte infusion as treatment for relapsed chronic myelogenous leukemia after allogeneic bone marrow transplantation. Blood 1995;86:4337-4343.

33 Alyea EP, Soiffer RJ, Canning C, Neuberg D, Schlossman R, Pickett C, Collins H, Wang Y, Anderson KC, Ritz J: Toxicity and efficacy of defined doses of CD4(+) donor lymphocytes for treatment of relapse after allogeneic bone marrow transplant. Blood 1998;91:36713680.

34 Mackinnon S, Papadopoulos EB, Carabasi MH, Reich L, Collins NH, Boulad F, CastroMalaspina H, Childs BH, Gillio AP, Kernan NA, Small TM, Young JW, OReilly RJ: Adoptive immunotherapy evaluating escalating doses of donor leukocytes for relapse of chronic myeloid leukemia after bone marrow transplantation: Separation of graft-versus-leukemia responses from graft-versus-host disease. Blood 1995;86:1261-1268.

35 Guglielmi C, Arcese W, Dazzi F, Brand R, Bunjes D, Verdonck LF, Schattenberg A, Kolb HJ, Ljungman P, Devergie A, Bacigalupo A Gomez M, Michallet M, Elmaagacli A, Gratwohl A, Apperley J, Niederwieser D: Donor lymphocyte infusion for relapsed chronic myelogenous leukemia: Prognostic relevance of the initial cell dose. Blood 2002;100:397-405.

36 Schmid C, Alessandrino EP, Bunjes D, Ferrant A, Frassoni F, Gluckman E, Holler E, Jacobsen N, Ljungman P, Schattenberg A, Verdonck L, Kolb HJ: Treatment of relapsed AML and MDS after allogeneic stem cell transplantation with donor lymphocyte transfusion - A retrospective analysis of EBMT results (abstract). Blood 2000;96:477.

37 Woiciechowsky A, Regn S, Kolb H-J, Roskrow M: Leukemic dendritic cells generated in the presence of FLT3 ligand have the capacity to stimulate an autologous leukaemia-specific cytotoxic $\mathrm{T}$ cell response from patients with acute myeloid leukaemia. Leukemia 2001;15:246255.

38 Schmid C, Lange C, Salat C, Stoetzer O, Ledderose $\mathrm{G}$, Muth A, Schleuning M, Roskrow M Kolb H-J: Treatment of recurrent acute leukemia after marrow transplantation with donor cells and GM-CSF (abstract). Blood 1999; 94(suppl 1):668

39 Fleming DR, Greenwood ME, Garrison J, Geil JD, Romond EH: Lymphocyte infusion for delayed extramedullary relapse of acute leukemia following bone marrow transplantation. Leuk Lymphoma 1996;21:525-528.

40 Lokhorst HM, Schattenberg A, Cornelissen JJ, Thomas LLM, Verdonck L: Donor leukocyte infusions are effective in relapsed multiple myeloma after allogeneic bone marrow transplantation. Blood 1997;90:4206-4211.

41 Tricot G, Vesole DH, Jagannath S, Hilton J, Munshi N, Barlogie B: Graft-versus-myeloma effect: Proof of principle. Blood 1996;87:11961198.
42 Verdonck LF, Lokhorst HM, Dekker AW, Nieuwenhuis HK, Petersen EF. Graft-versusmyeloma effect in two cases. Lancet 1996;347: 800-801.

43 Salama M, Nevill T, Marcellus D, Parker P, Johnson M, Kirk A, Porter D, Giralt S, Levine JE, Drobyski W, Barrett AJ, Horowitz M, Collins RH: Donor leukocyte infusions for multiple myeloma. Bone Marrow Transplant 2000; 26:1179-1184.

44 Fuchs EJ, Seber A, Altomonte V, Braine HG, Humphrey RL, Jones RJ, Noga SJ, Schepers K, Wright SK, Vogelsang GB: Chemotherapy does not nullify the ability of donor lymphocyte infusions to mediate graft-versus-host reactions. Bone Marrow Transplant 1998;22:303305.

$45 \mathrm{du}$ Toit C, Novitzky N: Multiple myeloma: Infusions of low doses of donor lymphocytes are also effective in reversing disease recurrence after bone marrow transplantation. $\mathrm{Br} \mathrm{J}$ Haematol 1998;103:1210-1211.

46 Alyea E, Weller E, Schlossman R, Canning C, Webb I, Doss D, Mauch P, Marcus K, Fisher D, Freeman A, Parikh B, Gribben J, Soiffer R, Ritz J, Anderson K: T-cell-depleted allogeneic bone marrow transplantation followed by donor lymphocyte infusion in patients with multiple myeloma: Induction of graft-versus-myeloma effect. Blood 2001;98:934-939.

47 Kwak LW, Taub DD, Duffey PL, Bensinger WI, Bryant EM, Reynolds CW, Longo DL: Transfer of myeloma idiotype-specific immunity from an actively immunised marrow donor. Lancet 1995;345:1016-1020.

48 Collins RH, Jr., Goldstein S, Giralt S, Levine J, Porter D, Drobyski W, Barrett J, Johnson M, Kirk A, Horowitz M, Parker P: Donor leukocyte infusions in acute lymphocytic leukemia. Bone Marrow Transplant 2000;26:511-516.

49 Matsue K, Tabayashi T, Yamada K, Takeuchi $\mathrm{M}$ : Eradication of residual bcr-abl-positive clones by inducing graft-versus-host disease after allogeneic stem cell transplantation in patients with Philadelphia chromosome-positive acute lymphoblastic leukemia. Bone Marrow Transplant 2002;29:63-66.

50 Lawson SE, Darbyshire PJ: Use of donor lymphocytes in extramedullary relapse of childhood acute lymphoblastic leukaemia following bone marrow transplantation. Bone Marrow Transplant 1998;22:829-830.

51 van Besien KW, de Lima M, Giralt SA, Moore DF, Jr., Khouri IF, Rondon G, Mehra R, Andersson BS, Dyer C, Cleary K, Przepiorka D, Gajewski JL, Champlin RE: Management of lymphoma recurrence after allogeneic transplantation: The relevance of graft-versus-lymphoma effect. Bone Marrow Transplant 1997; 19:977-982.

52 Childs R, Chernoff A, Contentin N, Bahceci E, Schrump D, Leitman S, Read EJ, Tisdale J, Dunbar C, Linehan WM, Young NS, Barrett AJ: Regression of metastatic renal-cell carcinoma after nonmyeloablative allogeneic peripheral-blood stem-cell transplantation. N Engl J Med 2000;343:750-758.
53 Or R, Ackerstein A, Nagler A, Kapelushnik J, Samuel S, Amar A, Brautbar C, Slavin S: Allogeneic cell-mediated immunotherapy for breast cancer after autologous stem cell transplantation: A clinical pilot study. Cytokines Cell Mol Ther 1998;4:1-6.

54 Horwitz ME, Barrett AJ, Brown MR, Carter CS, Childs R, Gallin JI, Holland SM, Linton GF, Miller JA, Leitman SF, Read EJ, Malech HL: Treatment of chronic granulomatous disease with nonmyeloablative conditioning and a T-cell-depleted hematopoietic allograft. N Engl J Med 2001;344:881-888.

55 Slavin S, Nagler A, Varadi G, Or R: Graft vs autoimmunity following allogeneic non-myeloablative blood stem cell transplantation in a patient with chronic myelogenous leukemia and severe systemic psoriasis and psoriatic polyarthritis. Exp Hematol 2000;28:853-857.

56 de Bueger M, Bakker A, Van Rood JJ, Van der Woude F,Goulmy E: Tissue distribution of human minor histocompatibility antigens. Ubiquitous versus restricted tissue distribution indicates heterogeneity among human cytotoxic T lymphocyte-defined non-MHC antigens. J Immunol 1992;149:1788-1794.

57 Vogt MH, de Paus RA, Voogt PJ, Willemze R, Falkenburg JH: DFFRY codes for a new human male-specific minor transplantation antigen involved in bone marrow graft rejection. Blood 2000;95:1100-1105.

58 Warren EH, Gavin MA, Simpson E, Chandler P, Page DC, Disteche C, Stankey KA, Greenberg PD, Riddell SR: The human UTY gene encodes a novel HLA-B8-restricted H-Y antigen. J Immunol 2000;164:2807-2814.

59 Vogt MH, van den Muijsenberg JW, Goulmy E, Spierings E, Kluck P, Kester MG, van Soest RA, Drijfhout JW, Willemze R, Falkenburg JH: The DBY gene codes for an HLA-DQ5restricted human male-specific minor histocompatibility antigen involved in graft-versushost disease. Blood 2002;99:3027-3032.

60 Zorn E, Wang KS, Hochberg EP, Canning C, Alyea EP, Soiffer RJ, Ritz J: Infusion of CD4+ donor lymphocytes induces the expansion of $\mathrm{CD} 8+$ donor $\mathrm{T}$ cells with cytolytic activity directed against recipient hematopoietic cells. Clin Cancer Res 2002;8:2052-2060.

61 Bonnet D, Warren EH, Greenberg PD, Dick JE, Riddell SR: CD8+ minor histocompatibility antigen-specific cytotoxic $\mathrm{T}$ lymphocyte clones eliminate human acute myeloid leukemia stem cells. Proc Natl Acad Sci USA 1999; 96:8639-8644.

62 Fontaine P, Roy-Proulx G, Knafo L, Baron C, Roy DC, Perreault C: Adoptive transfer of minor histocompatibility antigen-specific T lymphocytes eradicates leukemia cells without causing graft-versus host disease. Nat Med 2001;7:789-794.

63 Falkenburg JH, Wafelman AR, Joosten P, Smit WM, van Bergen CA, Bongaerts R, Lurvink E, van der Hoorn M, Kluck P, Landegent JE, Kluin-Nelemans HC, Fibbe WE, Willemze R: Complete remission of accelerated phase chronic myeloid leukemia by treatment with leukemia-reactive cytotoxic $\mathrm{T}$ lymphocytes. Blood 1999;94:1201-1208. 
64 Slavin S, Ackerstein A, Morecki S, Gelfand Y, Cividalli G: Immunotherapy of relapsed resistant chronic myelogenous leukemia post allogeneic bone marrow transplantation with alloantigen pulsed donor lymphocytes. Bone Marrow Transplant 2001;28:795-798.

65 Clave E, Molldrem J, Hensel N, Raptis A, Barrett AJ: Donor-recipient polymorphism of the proteinase 3 gene: A potential target for T-cell alloresponses to myeloid leukemia. J Immunother 1999;22:1-6.

66 Bocchia M, Korontsvit T, Xu Q, Mackinnon S, Yang SY, Sette A, Scheinberg DA: Specific human cellular immunity to bcr-abl oncogenederived peptides. Blood 1996;87:3587-3592.

67 Pinilla-Ibarz J, Cathcart K, Korontsvit T, Soignet S, Bocchia M, Caggiano J, Lai L, Jimenez J, Kolitz J, Scheinberg DA: Vaccination of patients with chronic myelogenous leukemia with bcr-abl oncogene breakpoint fusion peptides generates specific immune responses. Blood 2000;95:1781-1787.

68 Eibl B, Ebner S, Duba Ch, Böck G, Romani N Gächter A, Nachbaur D, Schuler G, Niederwieser D: Philadelphia-chromosome positive dendritic cells (DC) of chronic myelocytic leukemia $(\mathrm{CML})$ patients induce primary cytotoxic T-cell responses to CML cells. Bone Marrow Transplant 1997;19(suppl 1):S33

69 Smit WM, Rijnbeck M, van Bergen CAM, de Paus RA, Willemze R, Falkenburg JHF: Dendritic cells generated from FACS sorted chronic myeloid leukemia (CML) precursor cells express BCR/ABL, and are potent stimulators for allogeneic T cells (abstract 1186). Br J Haematol 1996;93(suppl 2):313.

70 Choudhury BA, Liang J, Thomas EK, FloresRomo L, Xie QS, Agusala K, Sutaria S, Sinha I, Champlin RE, Claxton D: Dendritic cells derived in vitro from acute myelogenous leukemia cells stimulate autologous anti-leukemic Tcell responses. Blood 1999;93:780-786.

71 Schneider EM, Chen ZZ, Ellwart J, Wilmanns W, Kolb HJ: Immune phenotype of chronic myelogenous leukemia progenitor cells (abstract 319). Bone Marrow Transplant 1996; 17(suppl 1):S69.

72 Chen X, Regn S, Kolb H-J, Roskrow M: The generation of leukemic dendritic cells from patients with chronic myeloid leukemia (CML) using the combination of interferon- $\alpha$ and GMCSF (abstract). Blood 1999;94(suppl 1):529.
73 Varadi G, Ackerstein A, Ben Neriah S, Nagler A: Adoptive cell-mediated immunotherapy with interleukin-2 (IL-2) for relapsing lymphoblastic crisis following mismatched unrelated bone marrow transplantation in a chronic myelogenous leukemia patient. Bone Marrow Transplant 1998;21:93-96.

74 Wen XY, Mandelbaum S, Li ZH, Hitt M, Graham FL, Hawley TS, Hawley RG, Stewart AK: Tricistronic viral vectors co-expressing interleukin-12 (1L-12) and CD80 (B7-1) for the immunotherapy of cancer: preclinical studies in myeloma. Cancer Gene Ther 2001;8:361370

75 Claret EJ, Alyea EP, Orsini E, Pickett CC, Collins H, Wang Y, Neuberg D, Soiffer RJ, Ritz J: Characterization of $\mathrm{T}$ cell repertoire in patients with graft-versus-leukemia after donor lymphocyte infusion. J Clin Invest 1997;100:855866.

76 Bellucci R, Alyea EP, Weller E, Chillemi A, Hochberg E, Wu CJ, Canning C, Schlossman $\mathrm{R}$, Soiffer RJ, Anderson KC, Ritz J: Immunologic effects of prophylactic donor lymphocyte infusion after allogeneic marrow transplantation for multiple myeloma. Blood 2002;99: 4610-4617.

77 Epperson DE, Margolis DA, McOlash L, Janczak T, Barrett AJ: In vitro T-cell receptor $\mathrm{V}$ beta repertoire analysis may identify which $\mathrm{T}$ cell $\mathrm{V}$ beta families mediate graft-versus-leukaemia and graft-versus-host responses after human leucocyte antigen-matched sibling stem cell transplantation. Br J Haematol 2001;114: 57-62.

78 Craddock C, Szydlo RM, Dazzi F, Olavarria E, Cwynarski K, Yong A, Brookes P, de la Fuente J, Kanfer E, Apperley JF, Goldman JM: Cytomegalovirus seropositivity adversely influences outcome after T-depleted unrelated donor transplant in patients with chronic myeloid leukaemia: The case for tailored graft-versus-host disease prophylaxis. Br J Haematol 2001;112: 228-236.

79 Dermime S, Mavroudis D, Jiang YZ, Hensel $\mathrm{N}$, Molldrem J, Barrett AJ: Immune escape from a graft-versus-leukemia effect may play a role in the relapse of myeloid leukemias following allogeneic bone marrow transplantation. Bone Marrow Transplant 1997;19:989-999.
80 Au WY, Lie AK, Ma SK, Wan TS, Liang R, Leung YH, Kwong YL: Philadelphia (Ph) chromosome-positive chronic myeloid leukaemia relapsing as $\mathrm{Ph}$-negative leukaemia after allogeneic bone marrow transplantation. $\mathrm{Br} \mathrm{J}$ Haematol 2001;114:365-368.

81 Glass B, Uharek L, Gassmann W, Focks B, Bolouri H, Loeffler H, Mueller-Ruchholtz W: Graft-versus-leukemia activity after bone marrow transplantation does not require graft-versus-host disease. Ann Hematol 1992;64:255259.

82 Uharek L, Glass B, Zeis M, Dreger P, Steinmann J, Löffler H, Schmitz N: Abrogation of graft-vs. leukemia activity after depletion of $\mathrm{CD} 3+\mathrm{T}$ cells in a murine model of MHCmatched peripheral blood progenitor cell transplantation (PBPCT). Exp Hematol 1998;26: 93-99.

83 Sykes M, Preffer F, McAfee S, Saidman SL, Weymouth D, Andrews DM, Colby C, Sackstein R, Sachs DH, Spitzer TR: Mixed lymphohaemopoietic chimerism and graft-versus-lymphoma effects after nonmyeloablative therapy and HLA-mismatched bone-marrow transplantation. Lancet 1999;353:1755-1759.

84 Mapara MY, Kim YM, Wang SP, Bronson R Sachs DH, Sykes M: Donor lymphocyte infusions mediate superior graft-versus-leukemia effects in mixed compared to fully allogeneic chimeras: a critical role for host antigen-presenting cells. Blood 2002;100:1903-1909.

85 Ruggeri L, Capanni M, Urbani E, Perruccio K, Shlomchik WD, Tosti A, Posati S, Rogaia D, Frassoni F, Aversa F, Martelli MF, Velardi A: Effectiveness of donor natural killer cell alloreactivity in mismatched hematopoietic transplants. Science 2002;295:2097-2100.

86 Weber M, Lange C, Kolb HJ, Kolb HJ: CFUsuppression by T-Cells primed with DLA-identical dendritic cells (abstract). Bone Marrow Transplant 2000;25(suppl 1):S23.

87 Bonini C, Ferrari G, Verzelletti S, Servida P, Zappone E, Ruggieri L, Ponzoni M, Rossini S, Mavilio F, Traversari C, Bordignon C: HSVTK gene transfer into donor lymphocytes for control of allogeneic graft-versus-leukemia. Science 1997;276:1719-1724.

88 Weissinger EM, Franz M, Voss C, Kremmer E, Kolb H-J: Expression of HSV-TK suicide gene in primary $\mathrm{T}$ lymphocytes: The dog as a preclinical model. Cytokines Cell Mol Ther 2000; 6:25-33.
Kolb/Schmid/Chen/Woiciechowski/ Roskrow/Weber/Guenther/Ledderose/ Schleuning 